Article

\title{
Carbon Footprint of Dwelling Construction in Romania and Spain. A Comparative Analysis with the OERCO2 Tool
}

\author{
Patricia González-Vallejo ${ }^{1, *(\mathbb{C},}$, Radu Muntean ${ }^{2}{ }^{\mathbb{C}}$, Jaime Solís-Guzmán ${ }^{1}{ }^{\mathbb{D}}$ and \\ Madelyn Marrero ${ }^{1}$ (D) \\ 1 ArDiTec Research Group, Departament of Architectural Constructions II, Higher Technichal School of \\ Building Engineering, Universidad de Sevilla, 41012 Seville, Spain; jaimesolis@us.es (J.S.-G.); \\ madelyn@us.es (M.M.) \\ 2 Department of Civil Engineering, Transilvania University of Brasov, 500036 Brașov, Romania; \\ radu.m@unitbv.ro \\ * Correspondence: pgonzalez1@us.es; Tel.: +34-954-556-697
}

Received: 13 July 2020; Accepted: 17 August 2020; Published: 20 August 2020

\begin{abstract}
CO}_{2}$ emissions due to the construction sector represent $40 \%$ of the total, either directly by the use of the building or indirectly by the emissions incorporated in construction materials and products. It is important to achieve a change in this sector to introduce these concepts in a simple way. There are various tools for evaluating emissions in construction projects. In the present work, the OERCO2 tool is used. This work studies housing projects in two European countries belonging to significantly different regions, Spain (Andalusia) and Romania (Bucharest and Transylvania). Although concrete or masonry structures are mainly used in Romania, due to an increased demand for residential buildings in recent years, a new niche has appeared in the construction sector: metallic and mixed (metal-concrete) structures for multi-storied buildings. For these reasons, a comparison between concrete and metallic buildings can be made in order to highlight their environmental impact. Twenty-four projects are selected from Romanian projects with metallic structures, and Spanish projects with concrete structures. They are also differentiated according to the type of foundation used. As expected, buildings with a metallic structure have more economic and environmental impact than reinforced concrete. The materials with greater impact are metal, concrete, cement, and ceramic products. The potential of the tool for the evaluation of various construction solutions, materials, and project phases is demonstrated.
\end{abstract}

Keywords: carbon footprint; assessment tool; dwelling construction; cost control

\section{Introduction}

Various environmental reports carried out in recent years highlight the construction sector as one of the main consumers of energy and generators of $\mathrm{CO}_{2}$ emissions among the various industrial sectors, with estimates of $30-40 \%$ of the total environmental impact produced [1]. This concern has forced the appearance of different types of tools to assess these impacts: through certification and standardization, the promotion of international standards to use environmental labeling for construction products [2-5], the development and application of life cycle analysis (LCA) [6-8], and the environmental management of buildings from a life cycle perspective $[9,10]$. However, the implementation of these standards is not always easy to achieve, due to barriers of all kinds, economic, technical, practical, and cultural, which prevent professionals from selecting materials with less environmental impact [11,12].

If we focus on the analysis of the life cycle of buildings, the manufacturing and construction phase of the building life cycle, concentrated in a short period of time (1-2 years), causes the most 
intense environmental impact, mainly due to the consumption of concrete and steel for the structure, which represents a high percentage of the emissions produced during this phase $[13,14]$. This impact is diluted if the building's useful life is lengthened. The use and maintenance phase is generally responsible for $80-90 \%$ of the $\mathrm{CO}_{2}$ emissions generated during the life cycle of the building [15], almost $60 \%$ of which is caused by the demand for energy for heating and cooling [16]. This implies that, in new standards such as zero energy buildings, emissions during the construction phase represent a higher percentage of the total emissions throughout the life cycle [17]. Therefore, once the energy consumption during the use phase is reduced, researchers' attention should be focused on materials that require less energy for their production [18].

Most of the recent studies that propose methodologies to estimate the environmental impact of buildings or the application of ecological indicators to the case studies of buildings have focused on aspects such as LCA [19], the analysis of energy consumption throughout of the life cycle [20], the carbon footprint of the life cycle [21], or a combination of these methods [22,23]. In recent years, these studies have been incorporated into more powerful computing tools, which is generating a new field of action for LCA, as is the case for building information modeling (BIM) platforms [24].

However, the LCA methodology and its derivatives are not always easy to implement by non-specialized users, and neither is their communication. For this reason, other methodologies have been implemented that have a smaller scope but are easier to use and implement by the agents involved in construction. Among the most employed, we find the ecological footprint (EF) or the carbon footprint (CF). The $\mathrm{CF}$ is an indicator of emissions of greenhouse gases generated by a given process [25], which stands out due to its simplicity and direct relationship with the main objectives of the Kyoto Protocol [26], along with its easy application in decision-making and environmental policy [27]. There are a large number of bibliographic reviews related to the use of the CF indicator in construction [28], however, the results are not always comparable, due to the absence of a methodology that follows international standards [29]. For this reason, studies have also been carried out in recent years to establish scales that allow for the definition of reasonable ranges of $\mathrm{CO}_{2}$ emissions in construction processes [30].

Tools are in place that can ensure that new and already built buildings meet minimum requirements related to environmental sustainability. Most of these systems are currently developed by two international organizations [31]: the World Green Building Council (GBC), which develops tools from an international system to obtain sustainability data for buildings, adapting them to each country, and BRE Global is another independent organization that develops the BREEAM method.

In Spain, there is a variety of these tools that include the calculation of the CF of buildings in some way, for example, LEED or BREEAM, whose use has spread in the country thanks to national organizations such as the Spanish Green Building Council [32] and BREEAM Spain [33]. These tools include, among the categories evaluated, the $\mathrm{CO}_{2}$ emissions due to the production of construction materials and the operational energy consumption; however, the final score does not reflect these $\mathrm{CO}_{2}$ emissions, so it does not report each result separately for a better understanding and subsequent analysis of possible improvements.

However, other alternatives have emerged from various research projects in the last decade in Spain. For example, SpainGBC has presented VERDE tools [32], a set of environmental impact assessment tools for design assistance (HADES), new buildings (VERDE NE), rehabilitation (VERDE RH), and urban development (VERDE DU). In this set of tools, the CF obtains the highest percentage of the score, so it prevails over other sources of environmental impact. ECOMETRO is an open-source and online tool to measure the environmental impact of buildings [34]. The information generated is similar to an environmental product declaration (EPD), but it applies to entire buildings.

Highly specialized platforms such as the BEDEC cost database, SOFIAS tool [35], or E2CO2Cero [36] allow for the detailed calculation of $\mathrm{CO}_{2}$ emissions according to the bill of quantities of a project. BEDEC was developed by the Institute of Construction Technology of Catalonia (ITeC), and uses environmental data of construction materials from the Ecoinvent database [37], known for being 
one of the most complete environmental databases at the European level [38] and for its integration with Simapro LCA software [39]. The SOFIAS tool uses data from the OpenDAP database [31,35]. An intermediate solution is E2CO2Cero [36], supported by the Basque Government, which is a software that estimates the embodied energy and CF of a building according to the materials consumed and the construction processes [36]. This tool also has two different versions: complete and simplified. The first one requires the presentation of the bill of quantities of the project, which is considered the appropriate way to reach the general public and create social awareness. A table with the scopes of each tool is included (Table 1).

Table 1. Comparison of assessment methods.

\begin{tabular}{cccccccc}
\hline & Leed & Breeam & Verde & Ecometro & Sofias & Gabi & Green Homes \\
\hline Site and construction & $\mathrm{X}$ & $\mathrm{X}$ & $\mathrm{X}$ & $\mathrm{X}$ & $\mathrm{X}$ & $\mathrm{X}$ & $\mathrm{X}$ \\
Transport & $\mathrm{X}$ & $\mathrm{X}$ & & $\mathrm{X}$ & $\mathrm{X}$ & $\mathrm{X}$ & $\mathrm{X}$ \\
Energy management & $\mathrm{X}$ & $\mathrm{X}$ & $\mathrm{X}$ & $\mathrm{X}$ & $\mathrm{X}$ & $\mathrm{X}$ & $\mathrm{X}$ \\
Water management & $\mathrm{X}$ & $\mathrm{X}$ & $\mathrm{X}$ & $\mathrm{X}$ & $\mathrm{X}$ & $\mathrm{X}$ & $\mathrm{X}$ \\
Materials and resources management & $\mathrm{X}$ & $\mathrm{X}$ & $\mathrm{X}$ & $\mathrm{X}$ & $\mathrm{X}$ & $\mathrm{X}$ & $\mathrm{X}$ \\
Waste management & $\mathrm{X}$ & $\mathrm{X}$ & $\mathrm{X}$ & $\mathrm{X}$ & $\mathrm{X}$ & $\mathrm{X}$ & $\mathrm{X}$ \\
Comfort & $\mathrm{X}$ & $\mathrm{X}$ & $\mathrm{X}$ & $\mathrm{X}$ & & & $\mathrm{X}$ \\
Health & $\mathrm{X}$ & $\mathrm{X}$ & $\mathrm{X}$ & $\mathrm{X}$ & & & $\mathrm{X}$ \\
Environmental charges & $\mathrm{X}$ & $\mathrm{X}$ & $\mathrm{X}$ & $\mathrm{X}$ & $\mathrm{X}$ & $\mathrm{X}$ & $\mathrm{X}$ \\
Services & $\mathrm{X}$ & $\mathrm{X}$ & $\mathrm{X}$ & & & $\mathrm{X}$ & $\mathrm{X}$ \\
Economic aspects & & & $\mathrm{X}$ & & $\mathrm{X}$ & $\mathrm{X}$ & $\mathrm{X}$ \\
Social aspects & & & $\mathrm{X}$ & & & $\mathrm{X}$ & $\mathrm{X}$ \\
\hline
\end{tabular}

In Romania, the awareness of green buildings and sustainable building materials has increased significantly over the past 10 years. The first LEED and BREEAM certifications appeared in 2008-2009. Currently in Romania, there are 39 buildings with BREEAM certificates, 21 with LEED, 3 with DGNB (German Sustainable Building Council) [40], and more than 4600 houses and apartments certified or in progress within the GREEN HOMES certification scheme developed by the Romania Green Building Council (GBC) [41].

The tools used by Romanian evaluators to calculate $\mathrm{CO}_{2}$ emissions of buildings are One Click LCA, Integrated Environmental Solution (IES VE Pro) [42], GaBi [43], 360 Optimi [44], and others. All of these require data on the type of material, the name of the product, thickness, quantity, transport (distance and type), and durability.

Colliers International Romania used One Click LCA to calculate the entire building life cycle assessment for their first LEED v4 project, as part of LEED certification. The project aimed to achieve a Gold Level certification [45]. GaBi software [43] supported a study on the LCA methodology applied to optimize municipal solid waste management (MSW) systems in Cluj county, Romania.

Romania GBC has established procedures for EPDs to be easily integrated into environmental certification tools such as GREEN HOMES [41] and is promoting EPDs for the recognition of points in international LEED or BREEAM certification. In the case of the Living Building Challenge certification system, its materials category is designed to foster a successful materials economy that is non-toxic, transparent, and socially equitable [46].

In Romania, there is no accredited body to issue EPDs, and all declarations are issued by international entities. The National Institute for Research and Development in Buildings, Urban Planning and Regional Sustainable Development (URBAN INCERC), established in 2009, is the only recognized institution that tests materials and issues performance certifications.

Compared to Spain, in Romania, there are no tools such as the BEDEC cost database, SOFIAS, or the E2CO2Cero tool that can be used to calculate $\mathrm{CO}_{2}$ emissions. There is cost-estimating software based on the quantities of materials, labor, transportation, and equipment used for buildings, but they do not include parameters such as energy consumption, $\mathrm{CO}_{2}$ emissions, or other environmental data.

From this point of view, an instrument capable of estimating the CF of buildings, which is also available in Romania, is a necessity nowadays and may be important for the future development of 
the construction sector due to the possibility of increasing the awareness of all participants in the construction industry regarding environmental problems.

The experience of the authors in methodologies for calculating carbon footprints ( $\mathrm{CFs}$ ) is presented through an open-source software to estimate the CF of architectural projects from the design phase and the tool is part of the OERCO2 project [47]. It is developed for educational purposes and free access with an Erasmus Project granted by the European Union, and member countries include Spain and Romania. This research is part of the tool validation for the calculation of carbon emissions in the construction phase of the building life cycle $[47,48]$. In the present work, the OERCO2 tool evaluates the $\mathrm{CO}_{2}$ emissions of the construction phase, including the extraction and manufacture of materials, as well as the management of construction and demolition waste (RCD) and the economic impact, and is compared to the rest of the tools in Table 1. Even though it does not cover all the aspects, it is easy to use and free accessible, making it an interesting teaching tool for college students and professionals [47]. The tool is valid to evaluate projects at the design stage.

The performance of this tool is explained through a comparative analysis of projects in both countries, Spain and Romania, which are part of the OERCO2 project. Representative typologies are assessed. In the particular case of studies in Romania, the CF of seismic reinforcements [49] is assessed. Additionally, a sensitivity analysis of the tool in these case studies is done.

A list with corresponding acronyms is included: Life cycle analysis (LCA); ecological footprint (EF); carbon footprint (CF), Green Building Council (GBC); Andalusian construction information classification system (ACICS); basic costs (BCs), auxiliary costs (ACs); simple unitary costs (SCs); life cycle inventory (LCI); metallic structure (MS).

\section{Materials and Methods}

The methodology for assessing the CF of the construction of residential building is based on the bill of the quantities of the project and a classification system for construction work that breaks down this information for materials, labor, and machinery (Figure 1). Budgets for 140 different projects are analyzed and classified; their budgets are reorganized into a construction breakdown system (CBS) that makes it easy to make comparisons. This organizing system has been successfully applied in previous research to assess the ecological footprint of buildings [50-56] and to estimate the generation of construction waste [45].

For the quantification of resources, the Andalusian construction cost database (ACCD) and its information classification system (ACICS) $[57,58]$ are used, which estimate costs in the construction sector, and their use is mandatory in public works in Andalusia (Spain). The ACICS uses a hierarchical organization for work units. This is represented in Figure 2, with the example of a collector of the sewage system, showing categories called chapters, corresponding to the first two numbers of the code (for example, earthworks, foundations, installations, sewage system, etc.), which are subsequently divided into subcategories.

The base of the ACCD structure is formed by the basic costs (BCs), which are materials, machinery, or manpower, and those are added to form auxiliary costs (ACs) and simple unitary costs (SCs); the latter represent the various activities or work units (Figure 2). These three types of costs are those used by the OERCO2 tool for its calculations. The ASICS has been revised and adapted to construction in Romania through the analysis of housing construction projects facilitated by the project partners, but the costs refer to Spain to facilitate the comparison between countries.

Environmental data included in the OERCO2 software are obtained from the Ecoinvent database through Simapro, which was chosen to cover all the materials commonly used in the construction of buildings [57]. In order to obtain the $\mathrm{CO}_{2}$ emissions embodied in construction materials, their life cycle inventory (LCI) is analyzed by applying the Intergovernmental Panel on Climate Change (IPCC) 100a methodology, which is used by the carbon footprint indicator to isolate $\mathrm{CO}_{2}$ and other Greenhouse Gases (GHG) emissions from the LCI. A list of the main construction materials and their corresponding carbon footprints, as obtained from LCA data, is included in Table 2. 
Table 2. Average values of environmental impacts by family of materials [59].

\begin{tabular}{cc}
\hline Material & Carbon Footprint $\left(\mathbf{t ~} \mathbf{C O}_{\mathbf{2}}\right.$ eq./t) \\
\hline Soil & 0.007 \\
Wood & -0.992 \\
Concrete & 0.112 \\
Asphalt & 0.21 \\
Ceramic & 0.22 \\
Aggregates and Stones & 0.004 \\
Metals & 1.50 \\
Plastics & 3.25 \\
Glass & 0.669 \\
Plaster and Pastes & 0.002 \\
\hline
\end{tabular}

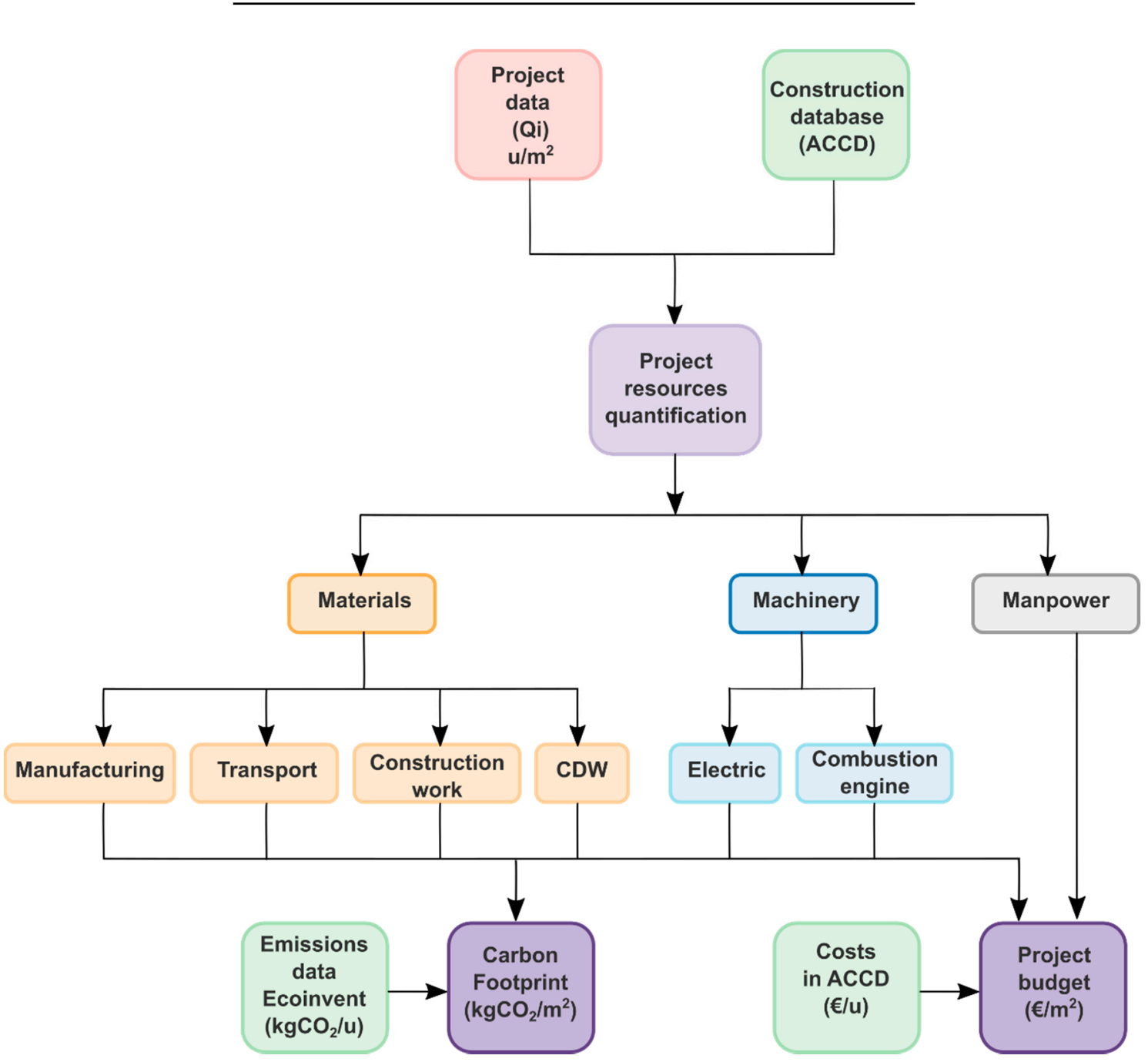

Figure 1. OERCO2 methodology. 


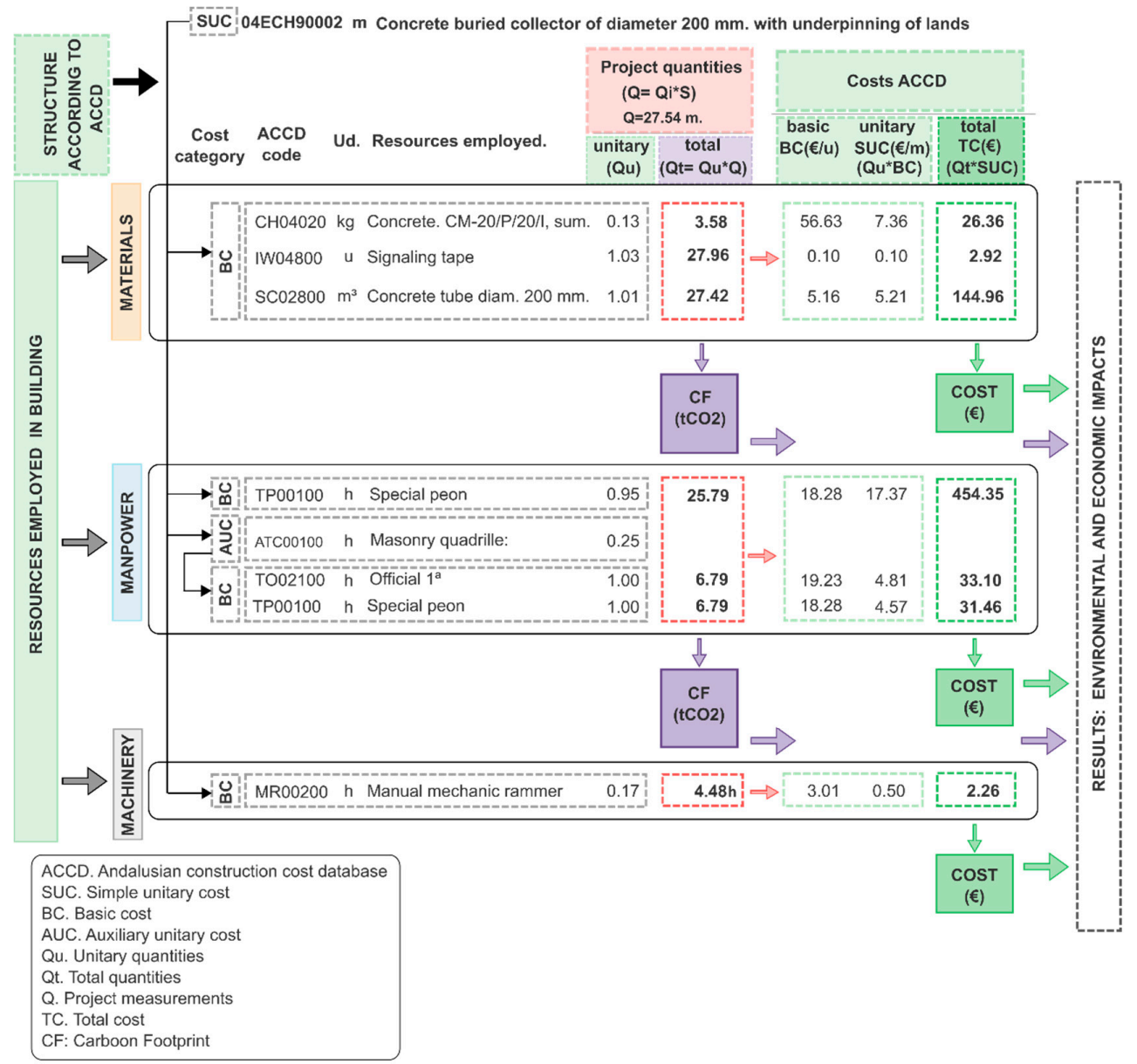

Figure 2. Cost and quantification of economic and Carbon Footprint (CF) model. Source: adapted from González-Vallejo et al. 2019 [56].

\section{OERCO2 Tool}

The OERCO2 tool [48] is an online application that allows for estimating the CF generated in the construction of residential buildings. It is derived from several previous research studies developed by the authors $[50,51,54-56,60,61]$ and includes the evaluation of $\mathrm{CO}_{2}$ emissions for the construction processes of 140 different types of residential buildings. The tool has been tested and evaluated by all the project partners and includes all the typologies and construction characteristics commonly used in Spain, Portugal, Italy, and Romania.

The data obtained from the bill of the quantities of each project are structured in accordance with the ACICS $[57,58]$ mentioned above and are expressed in units per surface constructed $\left(\mathrm{u} / \mathrm{m}^{2}\right)$. The average quantity of each activity (Qi) of the 140 evaluated projects is obtained through a statistic process for each type of construction according to the model to assess the construction of buildings $[50,62]$. These average quantities are transformed into materials, labor, and machinery. The amounts of the various resources involved is evaluated using the $\mathrm{CF}$ methodology to obtain the emissions of $\mathrm{CO}_{2}$ generated due to all the construction processes.

The OERCO2 tool has an initial screen where the user specifies general information about the project to be analyzed, such as number of floors, the type of structure, and floor area (Figure 3). The selection of these initial data allows for assigning one similar project from the database which collects the resource quantities needed in the building (Qi) $[50,60]$.

In the following step, the user specifies data on the project related to construction solutions for each element (Figure 3). The OERCO2 tool uses this information to select which of the available SCs should be used for calculations. As mentioned above, SCs are made up of BCs and ACs. In this 
tool, the resources (BCs) contain not only economic information, but also environmental information (for example, $\mathrm{CO}_{2}$ emission factor).

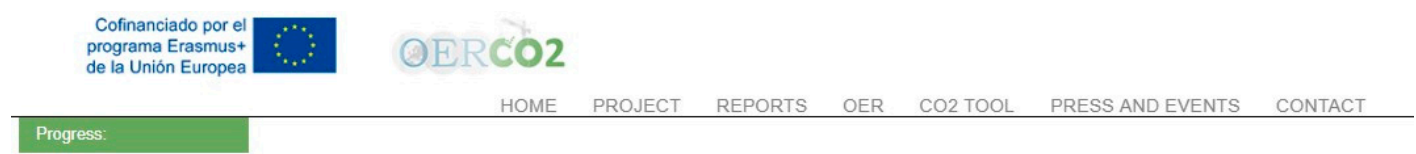

INITIAL DATA

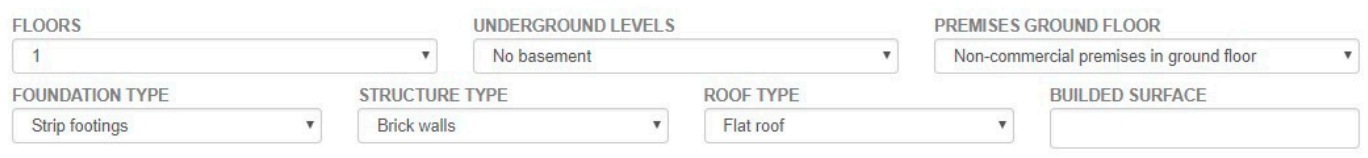

Figure 3. Selection interface for the initial data of the project in the OERCO2 tool [48].

Following this logic, when you select one specific work unit, the SC is assigned two factors: economic cost ( $€$ /unit of reference) and environmental cost ( $\mathrm{kg} \mathrm{CO}_{2} \mathrm{eq} /$ unit of reference), where the unit of reference is the selected SC (Figure 1). Initial data selection can meet the Qi of the work unit, which allows for obtaining the total cost and CF of this activity through Equations (1) to (4) whose factors are defined in Table 3.

$$
\begin{gathered}
\mathrm{CF}_{\mathrm{MAT}}=\left(\Sigma \mathrm{i} \mathrm{Cmi} \times \mathrm{UCF}_{\mathrm{MAT}}\right)+\left(\mathrm{UCF}_{\mathrm{TRAN}} \times \mathrm{Cmi}\right) \\
\mathrm{CF}_{\text {MCOMB }}=\mathrm{V} \times \mathrm{UCF}_{\mathrm{COMB}} \\
\mathrm{V}=(\mathrm{P} \times \mathrm{T} \times \mathrm{Ef}) \\
\mathrm{CF}_{\text {MELEC }}=(\mathrm{P} \times \mathrm{T}) \times \mathrm{UCF}_{\mathrm{ELEC}}
\end{gathered}
$$

Table 3. Factors to calculate CF of the construction phase of materials and machinery.

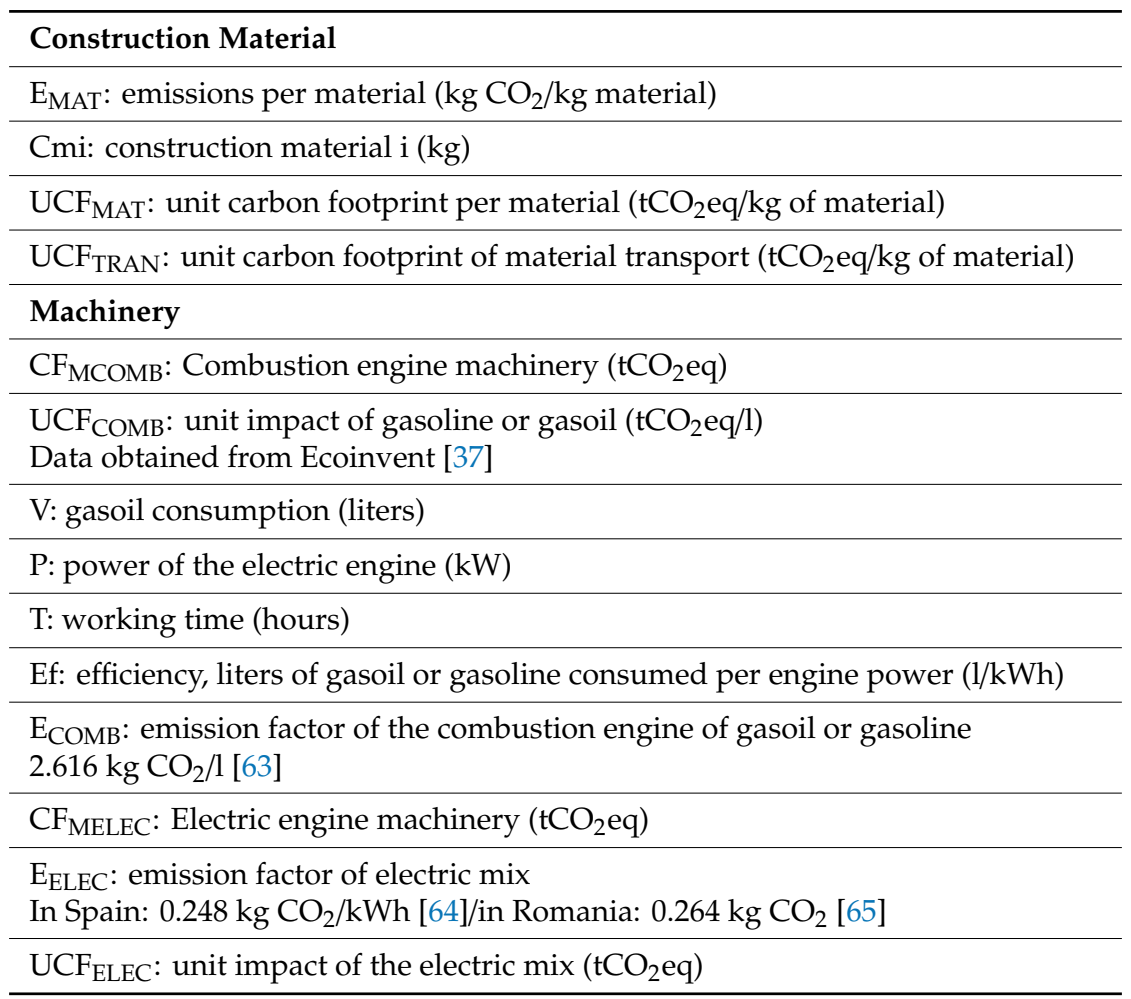


The transport of materials is included in the environmental impact by making approximations of the distance covered [66]. The transport is done by truck. As for the distance from the factory to the work site, most materials are manufactured close to the construction site, i.e., $250 \mathrm{~km}$. In the specific case of concrete, a maximum distance of $20 \mathrm{~km}$ is considered before solidification starts [67]. The tons of $\mathrm{CO}_{2}$ can be obtained with the data in Table 4. Material transport in Romania is similar to that in Andalusia, where pick-up points are in warehouses in peripheral zones, close to main cities. Fresh concrete has a similarly limited time for its transport.

Table 4. Data for calculating the impact of transport.

\begin{tabular}{lcc}
\hline & Concrete & Other Materials \\
\hline Truck load capacity $(\mathrm{t})$ & 24 & 2 \\
Distance to factory $(\mathrm{km})$ & 20 & 250 \\
Average diesel consumption $(\mathrm{l} / 100 \mathrm{~km})$ & 26 & 26 \\
Diesel emissions $\left(\mathrm{tCO}_{2} / \mathrm{l}\right)$ & $2.62 \times 10^{-3}$ & $2.62 \times 10^{-3}$ \\
Diesel consumed water $\left(\mathrm{m}^{3} / \mathrm{l}\right)$ & 1.26 & 1.26 \\
Diesel embodied energy $(\mathrm{MJ} / \mathrm{l})$ & 57.70 & 57.70 \\
Electricity embodied energy $(\mathrm{MJ} / \mathrm{kWh})$ & 3.60 & 3.60 \\
\hline
\end{tabular}

The tool displays the total cost of building construction (expressed in $€$ and $€ / \mathrm{m}^{2}$ ) and the total CF (in $\mathrm{kg} \mathrm{CO}$ eq and $\mathrm{kg} \mathrm{CO}_{2} \mathrm{eq} / \mathrm{m}^{2}$ ), the latter is also divided into materials and machinery (Figure 2).

In the OERCO2 tool, the users do not require specialized knowledge on the environmental evaluation of construction projects, such as the calculation of embodied energy or the $\mathrm{CO}_{2}$ emission factor associated with construction processes. Instead, the users only need to know the solutions implemented in the building's construction. The OERCO2 tool has been verified by all the partners in the project to include variations between countries in processes and construction solutions $[48,68]$.

\section{Case Studies}

Two project member countries are selected, for which building typologies are included in the OERCO2 tool, with Spain and Romania being two of the most remote countries and where more constructive differences can be found. The OERCO2 tool presents the alternative of concrete and metal structures, the latter option being included as it is a type of structure used in Romania, and therefore the analysis of these two countries and construction typologies is carried out.

Projects of Romanian (Bucharest and Transylvania) buildings with metal structures are studied and compared with the same typology of Spanish (Andalusia) buildings with a reinforced concrete structure. Although concrete or masonry structures are mainly used in Romania, due to an increased demand for residential buildings in recent years, the necessity to reduce the execution time, the necessity to improve quality and price control, the need for larger dimensions for open spaces, the development of automated execution technologies (welding), the increase in prices for formwork (especially labor), and the need for much better resilience, a new niche appeared in the construction sector: metallic and mixed (metal-concrete) structures for multi-storied buildings. A very important feature of metal structures is their multifunctionality and their ability to adapt, modify, and rebuild, as well as better seismic behavior, Romania being a country characterized by relatively strong earthquakes. Steel parts are prefabricated according to specific standards, are easy to transport, and their assembly is fast, with low costs and low dependence on environmental conditions [49].

Firstly, the current situation of construction in Romania is studied and the OERCO2 tool methodology is applied to residential buildings and compared with the study carried out in Spain. The chosen typology in both countries is the multi-family residential building, with the same number of floors below and above ground, with one of three different types of foundations, isolated footings, reinforced slab, and piles. Both countries use the most common constructive systems. 


\subsection{Statistical Data}

From the statistical data, the most representative type of project in Romania is obtained. According to Table 5, dwellings represents nearly $80 \%$ of the buildings constructed since 2014, with an average floor area per apartment of $113 \mathrm{~m}^{2}$ [69]. This percentage remains stable very year.

Data reflected in Table 5 justify the study of housing construction since it is an important sector and it maintains a stable rhythm of new buildings in 2015, slightly decreases in 2016, and goes up in 2017 and 2018, even exceeding previous years. The data are based on the total number of permits issued for residential buildings, with a large number of apartments/housing (units) finally authorized to be built, obtaining the total floor area in the last column.

Table 5. Statistical data of new buildings in Romania between 2014 and 2018.

\begin{tabular}{ccccccc}
\hline Year & $\begin{array}{c}\text { Number of Permits } \\
\text { for Residential } \\
\text { Buildings }\end{array}$ & $\begin{array}{c}\text { Administrative } \\
\text { Buildings }\end{array}$ & Others & $\begin{array}{c}\text { Total } \\
\text { Number of } \\
\text { Permits }\end{array}$ & Apartments & $\begin{array}{c}\text { Total Floor Area, } \\
\text { Residential }\left(\mathbf{m}^{2}\right)\end{array}$ \\
\hline 2014 & 37,672 & 234 & 7568 & 45,474 & 60,270 & $7,162,041$ \\
\hline 2015 & 39,112 & 237 & 7164 & 46,513 & 67,293 & $7,839,961$ \\
\hline 2016 & 38,653 & 196 & 6185 & 45,034 & 80,608 & $8,892,555$ \\
\hline 2017 & 41,603 & 204 & 6551 & 48,358 & 88,029 & $9,628,297$ \\
\hline 2018 & 42,694 & 255 & 7170 & 50,119 & 98,103 & $10,664,822$ \\
\hline
\end{tabular}

The dwelling characteristics, according to the report entitled "National Housing Strategy" and published by the Romanian Ministry of Environment, Water and Forests [70] in 2015, states that, in urban areas, approximately $70 \%$ of the housing units in Romania were multi-family buildings (blocks of flats/apartments) of 10 apartments or more, and the rest were individual dwellings. The building height was limited because elevators have high costs for construction and operation. The majority of multi-storied buildings were up to five floors, consisting in the ground floor and four upper floors [71]. Fewer floors were not economically feasible in terms of total floor area per lot.

In the case of Spain, according to data taken between the years 2007-2010 from the National Statistics Institute (INE) [72] and published studies [62], 78\% of the constructed buildings were residential, of which $33 \%$ correspond to the type of building with four or five floors above ground.

\subsection{Selected Projects}

Once the statistical study was carried out, 24 types of projects were selected in Romania and 24 projects in Spain, in the OERCO2 tool, in Tables 6 and 7, Romanian projects have metallic structures, and in Spain, reinforced concrete structures. Both types of projects are also classified according to type of foundation, isolated footings, reinforced concrete slab, and piles. The roof could be inclined or horizontal and there are buildings with a basement (one or two floors) and without a basement. The use on the ground floor can be for premises or houses. Table 6 includes the general characteristics that are common in the 48 projects. The different construction characteristics between Romania and Spain are defined in Table 7. Data for Spain are based on the INE data that have already been analyzed [62].

Table 6. General information of selected buildings in OERCO2 tool.

\begin{tabular}{ccccc}
\hline \multirow{2}{*}{$\begin{array}{c}\text { General } \\
\text { information }\end{array}$} & 5 & $\begin{array}{c}\text { Number of } \\
\text { Underground Floors }\end{array}$ & Use of Ground Floor \\
\cline { 2 - 4 } & Foundation & $0 / 1 / 2$ & Shops/dwelling \\
\cline { 2 - 4 } & $\begin{array}{c}\text { Isolated Footings/Reinforced } \\
\text { Slab/Piles }\end{array}$ & $\begin{array}{c}\text { Metal/Reinforced } \\
\text { Concrete }\end{array}$ & Flat/Sloping & 72 \\
\hline
\end{tabular}


Table 7. Selected data for the case studies from OERCO2 tool.

\begin{tabular}{|c|c|c|c|c|}
\hline \multicolumn{5}{|c|}{ MS and CS Buildings (Romania and Spain) } \\
\hline \multirow{12}{*}{ 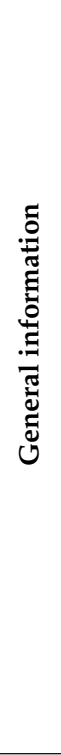 } & \multicolumn{4}{|c|}{ Earthworks } \\
\hline & Excavations & Fillings & \multicolumn{2}{|c|}{ Earth Transport } \\
\hline & Excavator & Mechanic means & \multicolumn{2}{|c|}{ Mechanic means } \\
\hline & \multicolumn{4}{|c|}{ Sewer System } \\
\hline & Manholes & Sewage pipes & \multicolumn{2}{|c|}{ Downpipes and roof sinks } \\
\hline & In situ & PVC & \multicolumn{2}{|c|}{ Reinforced PVC } \\
\hline & \multicolumn{4}{|c|}{ Structure } \\
\hline & Formwork & Floor slabs & Flat roof & Sloping roof \\
\hline & Metallic & $\begin{array}{l}\text { Waffle slab with recoverable } \\
\text { caissons/One-way slab with } \\
\text { concrete vaults }\end{array}$ & $\begin{array}{c}\text { Passable and } \\
\text { ventilated/Passable and } \\
\text { inverted }\end{array}$ & Ceramic tiles \\
\hline & \multicolumn{4}{|c|}{ Masonry } \\
\hline & Façades & \multicolumn{2}{|c|}{ Claddings } & Partitions \\
\hline & $\begin{array}{c}\text { One-foot brick wall with } \\
\text { chamber/0.5-foot brick wall with } \\
\text { chamber }\end{array}$ & \multicolumn{2}{|c|}{ Single layer mortar } & $\begin{array}{l}\text { Double hollow } \\
\text { brick } 9 \mathrm{~cm}\end{array}$ \\
\hline \multirow{15}{*}{ 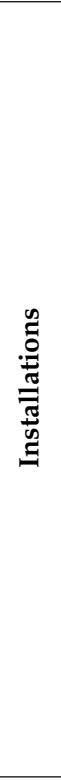 } & \multicolumn{4}{|c|}{ Air-Conditioning System } \\
\hline & Air-Conditioning & Terminal units & Ducts & Pipes \\
\hline & None & None & None & None \\
\hline & \multicolumn{2}{|c|}{ Heating } & \multicolumn{2}{|c|}{ Insulation } \\
\hline & Radiators & Boiler & \multicolumn{2}{|c|}{ Pipe insulation } \\
\hline & Classic steel & Gasoil & \multicolumn{2}{|c|}{ Applies } \\
\hline & \multicolumn{4}{|c|}{ Water supply and ventilation } \\
\hline & Cold-water pipes & Hot-water pipes & Sinks & Ventilation \\
\hline & Copper & Copper & PVC & Concrete \\
\hline & \multicolumn{4}{|c|}{ Domestic Hot water } \\
\hline & Heater & \multicolumn{3}{|c|}{ Solar panels } \\
\hline & Gas & \multicolumn{3}{|c|}{ Applies/Does not apply } \\
\hline & \multicolumn{4}{|c|}{ Accessibility } \\
\hline & \multicolumn{4}{|c|}{ Lift } \\
\hline & \multicolumn{4}{|c|}{ Applies } \\
\hline \multirow{12}{*}{ 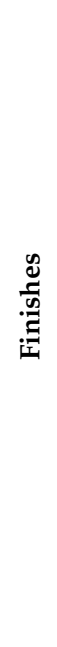 } & Insula & & \multicolumn{2}{|c|}{ Vertical finishing } \\
\hline & Thermal- & oustic & Continuo & \\
\hline & Polyurethane & ock wool & Renderir & \\
\hline & & Finishes & & \\
\hline & Floo & & Ceiling & \\
\hline & Cerar & & Continuous lamina & d gypsum \\
\hline & & Carpentry & & \\
\hline & Windows & Glazi & & Doors \\
\hline & $\begin{array}{l}\text { Lacquered aluminum casement } \\
\text { with thermal bridge break }\end{array}$ & Thermal-acous & $6+12+6$ & Wood \\
\hline & & Protection element & & \\
\hline & Blinds & Protectio & grids & Railings \\
\hline & Anodized aluminum & Hot-rolle & steel & Steel \\
\hline
\end{tabular}


Table 7 includes the data selected in the tool for both cases according to the proposed alternatives, which are similar except for the type of slab, horizontal roof construction system, façade cladding, and type of insulation. Additionally, solar panels for domestic hot water are installed in Spain.

\section{Results and Discussion}

According to the characteristics of the projects proposed from the statistical analysis of each country, the 48 projects' data are classified and coded according to the OERCO2 tool information in Table 8 and average values are obtained, the numbers are generic for the software and do not have a specific meaning. The comparison is not only of Spanish and Romanian projects but also different constructive solutions are employed in each country that give rise to 24 combinations in each (Table 8). The codes are defined to identify the differences in the combinations as set in Table 8: column foundation, number underground floors, ground floor, and roof type. The MS and CS coding corresponds to the typical metal structure projects in Romania and the concrete structures of the projects in Spain, respectively. The numeric codes are those internally used by the software.

Table 8. Classification and codification of projects according to the OERCO2 tool, MS is metallic structure and CS is reinforced concrete structure.

\begin{tabular}{|c|c|c|c|c|c|}
\hline Foundation & $\begin{array}{c}\text { Number } \\
\text { Underground Floors }\end{array}$ & Ground Floor & Roof Type & $\begin{array}{c}\text { MS } \\
\text { OERCO2 } \\
\text { Code }\end{array}$ & $\begin{array}{c}\text { CS } \\
\text { OERCO2 } \\
\text { Code }\end{array}$ \\
\hline \multirow{4}{*}{$\begin{array}{l}\text { ISOLATED } \\
\text { FOOTINGS }\end{array}$} & \multirow{4}{*}{0} & \multirow{2}{*}{ Dwelling } & Flat & M012 & C012 \\
\hline & & & Sloping & M013 & $\mathrm{C} 013$ \\
\hline & & \multirow{2}{*}{ Shops } & Flat & M021 & C021 \\
\hline & & & Sloping & M025 & $\mathrm{C} 025$ \\
\hline \multirow{4}{*}{$\begin{array}{l}\text { ISOLATED } \\
\text { FOOTINGS }\end{array}$} & \multirow{4}{*}{1} & \multirow{2}{*}{ Dwelling } & Flat & M043 & $\mathrm{C} 043$ \\
\hline & & & Sloping & M051 & C051 \\
\hline & & \multirow{2}{*}{ Shops } & Flat & M040 & $\mathrm{C} 040$ \\
\hline & & & Sloping & M048 & C048 \\
\hline \multirow{2}{*}{$\begin{array}{l}\text { REINFORCED } \\
\text { SLAB }\end{array}$} & \multirow{2}{*}{0} & \multirow{2}{*}{ Shops } & Flat & M106 & C106 \\
\hline & & & Sloping & M110 & C110 \\
\hline \multirow{4}{*}{$\begin{array}{l}\text { REINFORCED } \\
\text { SLAB }\end{array}$} & \multirow{4}{*}{1} & \multirow{2}{*}{ Dwelling } & Flat & M090 & C090 \\
\hline & & & Sloping & M098 & C098 \\
\hline & & \multirow{2}{*}{ Shops } & Flat & M094 & C094 \\
\hline & & & Sloping & M102 & C102 \\
\hline \multirow{2}{*}{$\begin{array}{l}\text { REINFORCED } \\
\text { SLAB }\end{array}$} & \multirow{2}{*}{2} & \multirow{2}{*}{ Dwelling } & Flat & M147 & C147 \\
\hline & & & Sloping & M148 & C148 \\
\hline \multirow{4}{*}{ PILES } & \multirow{4}{*}{0} & \multirow{2}{*}{ Dwelling } & Flat & M062 & C062 \\
\hline & & & Sloping & M054 & $\mathrm{C} 054$ \\
\hline & & \multirow{2}{*}{ Shops } & Flat & M066 & $\mathrm{C} 066$ \\
\hline & & & Sloping & M059 & C059 \\
\hline \multirow{4}{*}{ PILES } & \multirow{4}{*}{0} & \multirow{2}{*}{ Dwelling } & Flat & M083 & C083 \\
\hline & & & Sloping & M082 & C082 \\
\hline & & \multirow{2}{*}{ Shops } & Flat & M081 & C081 \\
\hline & & & Sloping & M080 & C080 \\
\hline
\end{tabular}

From the building typology and construction characteristics of the projects, the unit (Qi) and total (Qt) quantification of each project is obtained, from which the economic and CF results are obtained, and included in Supplementary Data Tables S1 and S2 (Romania and Spain, respectively).

The quantity of materials used in the projects is analyzed according to the weight, expressed in $\mathrm{kg}$, in addition to the $\mathrm{CF}$, and, finally, the $\mathrm{CF}$ is calculated for the construction phases of the projects. 
Materials are grouped in families: concrete and cement, ceramics and bricks, aggregates and stones, and metals and alloys represent around $80 \%$ of the total weight.

In Figure 4, the materials are analyzed according to the weight of metallic structure (MS) buildings in Romania, and in Figure 5, concrete structure (CS) buildings in Spain. Buildings with an MS need a larger amount of materials, except in the case of aggregates, whose values are similar in both cases. Concrete and cement are the heaviest materials in both countries. Pile foundation buildings have the highest consumption, followed by those of isolated footings and finally of reinforced slab. Ceramics and bricks have a higher consumption in Romanian buildings, since façade cladding is thicker than in Spain. Aggregates and stones are used almost equally in the three types of foundations. Lastly, metals and alloys have a higher consumption, as expected, in MS buildings.

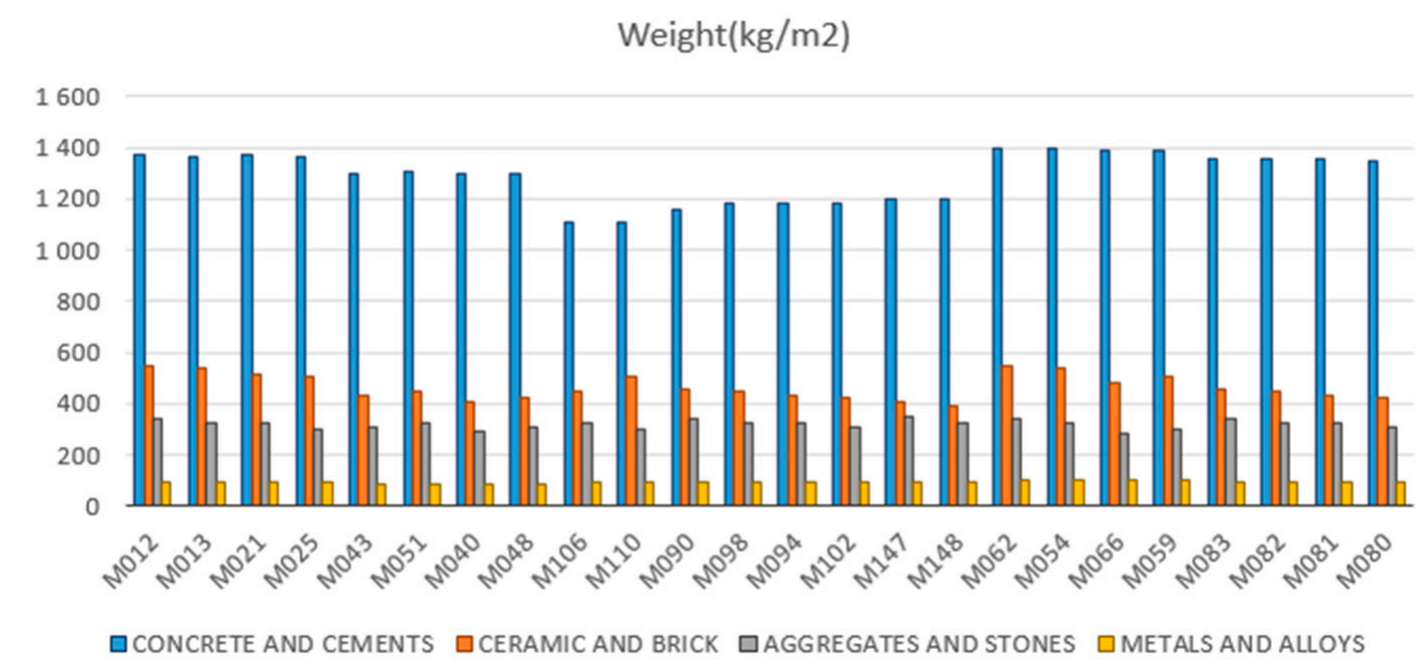

Figure 4. Weight per floor area $\left(\mathrm{kg} / \mathrm{m}^{2}\right)$ of families of materials (Romania).

\section{Weight $(\mathrm{kg} / \mathrm{m} 2)$}

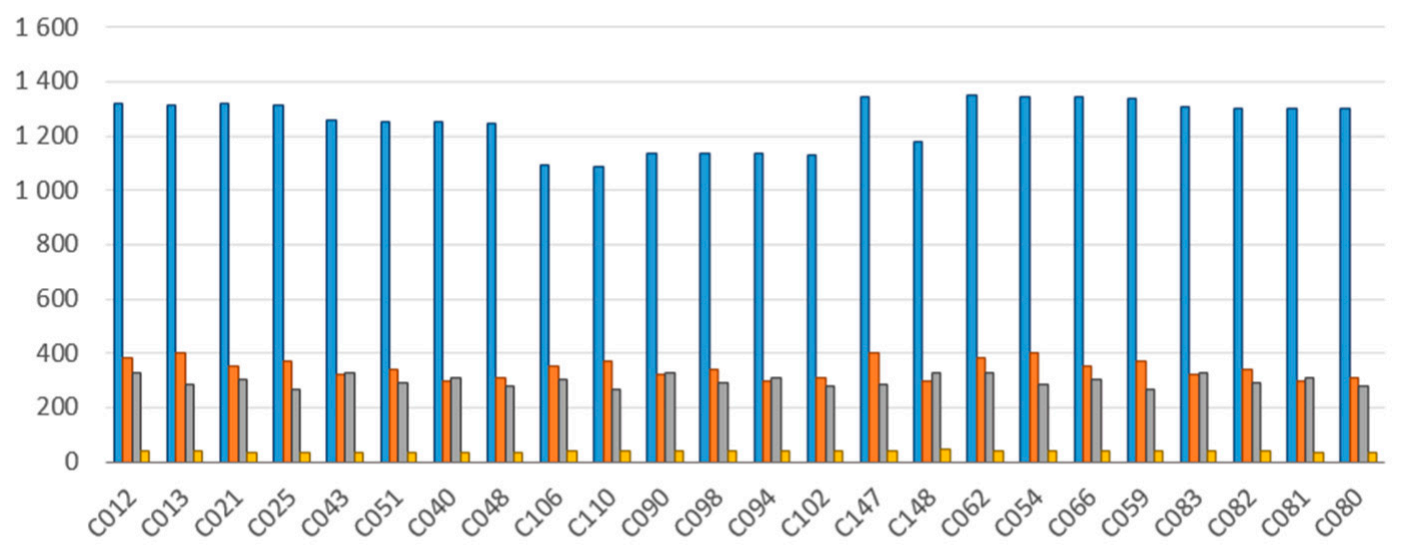

$\square$ CONCRETE AND CEMENTS $\square$ CERAMIC AND BRICK $\square$ AGGREGATES AND STONES $\square$ METALS AND ALLOYS

Figure 5. Weight per floor area $\left(\mathrm{kg} / \mathrm{m}^{2}\right)$ of families of materials (Spain).

The analysis of the CF of materials introduces a new important family, plastics. Figure 6 shows that MS buildings in Romania produce a greater impact than those in Spain with CS (Figure 7) for all the families, except plastics, due to the use of projected polyurethane insulation in CS buildings. In MS projects (Figure 6), metals/alloys and concretes/cements produce the greatest $\mathrm{CF}$, as the buildings with piles produce a slightly greater impact compared to the other two types. Ceramics/bricks also produce high CF values, due to their use in façades and interior cladding, and lastly plastics. However, in the case of CS buildings (Figure 7), the greatest impact is produced by concretes/cements, with those with 
piles and isolated footing being more polluting than those of reinforced slab. Ceramics/bricks have a much smaller impact, since Spanish buildings have less thick façades than Romanian ones, followed by metals and alloys, and then plastics. These results are similar to those of other studies [48].

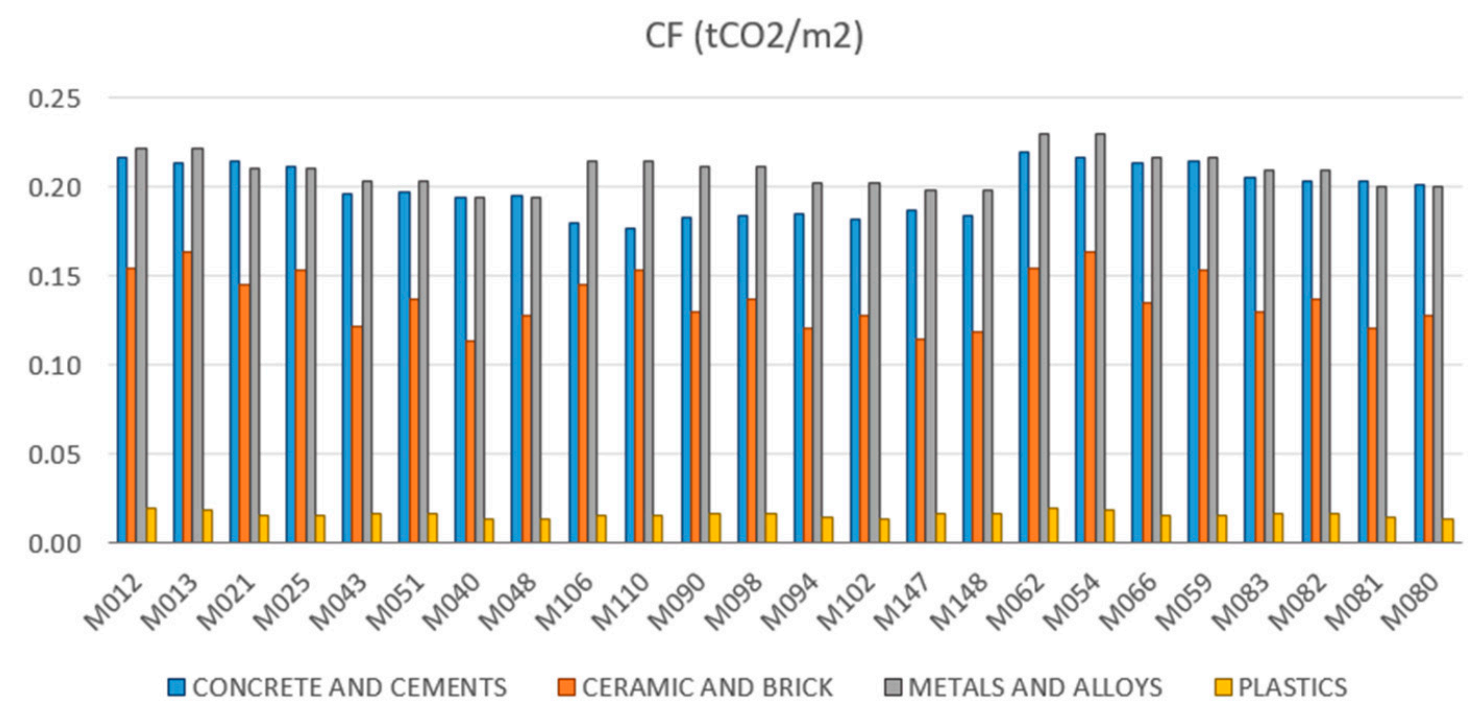

Figure 6. CF per area $\left(\mathrm{tCO}_{2} / \mathrm{m}^{2}\right)$ by family of materials (Romania).

\section{$\mathrm{CF}(\mathrm{tCO} 2 / \mathrm{m} 2)$}

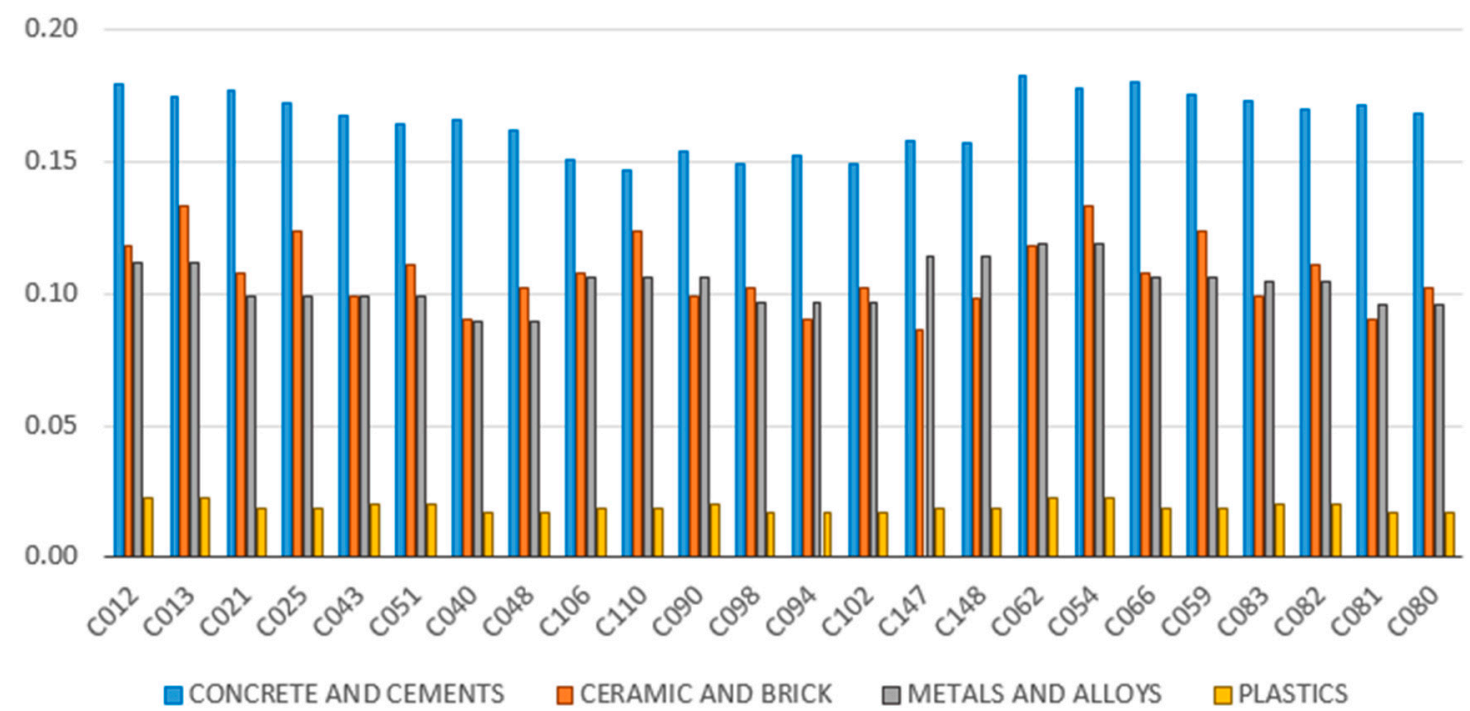

Figure 7. $\mathrm{CF}$ per area $\left(\mathrm{tCO}_{2} / \mathrm{m}^{2}\right)$ by family of materials (Spain).

The patterns in Figures 4-7 are due to the project classification in Table 6, first fixing foundations, then the number of underground floors, followed by the type of construction, such as ground level use, and, finally, the roof type.

Simple costs included in the OERCO2 tool with the greatest impact (according to the ACCD) are 3HAL00002 ( $\mathrm{m}^{3}$ slab concrete); 03HMM00002 ( $\mathrm{m}^{3}$ mass concrete); 03CPS00007 (m pile on site); 05HHJ0010 ( $\mathrm{m}^{3}$ concrete assembled on beams); 05FBB00007 ( $\mathrm{m}^{2}$ waffle slab with concrete caissons); 05FUS00007 ( $\mathrm{m}^{2}$ one-way slab with concrete vaults); 05ACS00000 ( $\mathrm{kg}$ steel in hot-rolled profiles); 05HAC00015 (kg corrugated steel in bars); 06LMM00101 ( $\mathrm{m}^{2}$ one-foot brick wall); 06LPC00001 $\left(\mathrm{m}^{2}\right.$ 0.5-foot brick wall).

The following analysis is carried out by the construction phases or chapters of the project, as shown in Figure 8 (Romania) and Figure 9 (Spain). It is observed that the chapter with the greatest impact is 
structures in MS buildings and then the chapter of installations in CS buildings, due to solar panels, which have been mandatory in the construction of new housing in Spain since 2006. The next chapter that produces the greatest impact is masonry, in both countries, including ceramics/bricks for their use in façades, claddings, and partitions. The next important $\mathrm{CF}$ value is produced by the foundation phase, with the piles producing the greatest impact in both countries, followed by isolated footings and, lastly, with little difference, reinforced slabs. Of the five chapters, the one with the least impact is that of finishes, with similar values in all the cases analyzed since there are no variations in the construction systems and/or materials used.

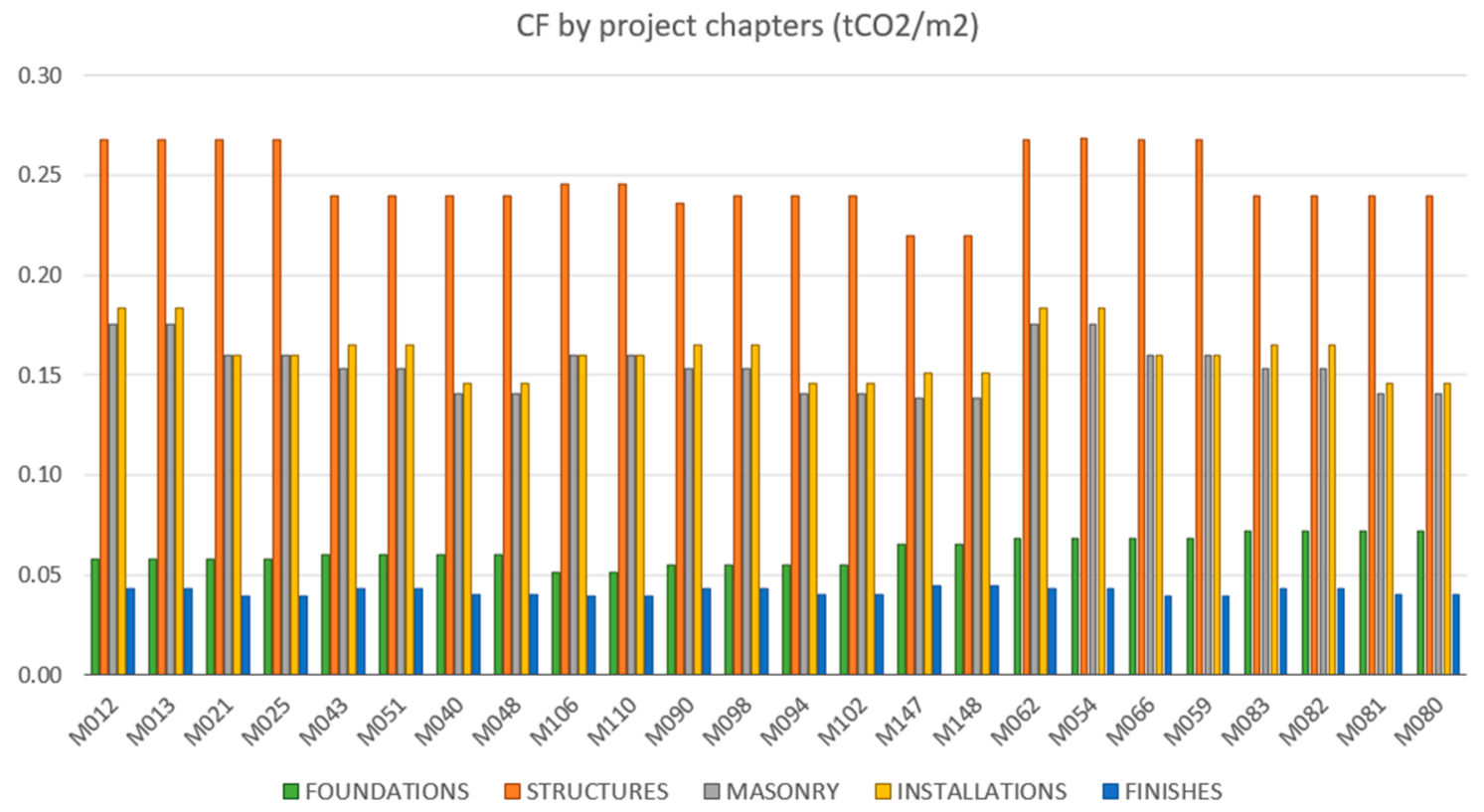

Figure 8. $\mathrm{CF}$ per area $\left(\mathrm{tCO}_{2} / \mathrm{m}^{2}\right)$ according to chapter of project (Romania).

CF by project chapters (tCO2/m2)

0.25

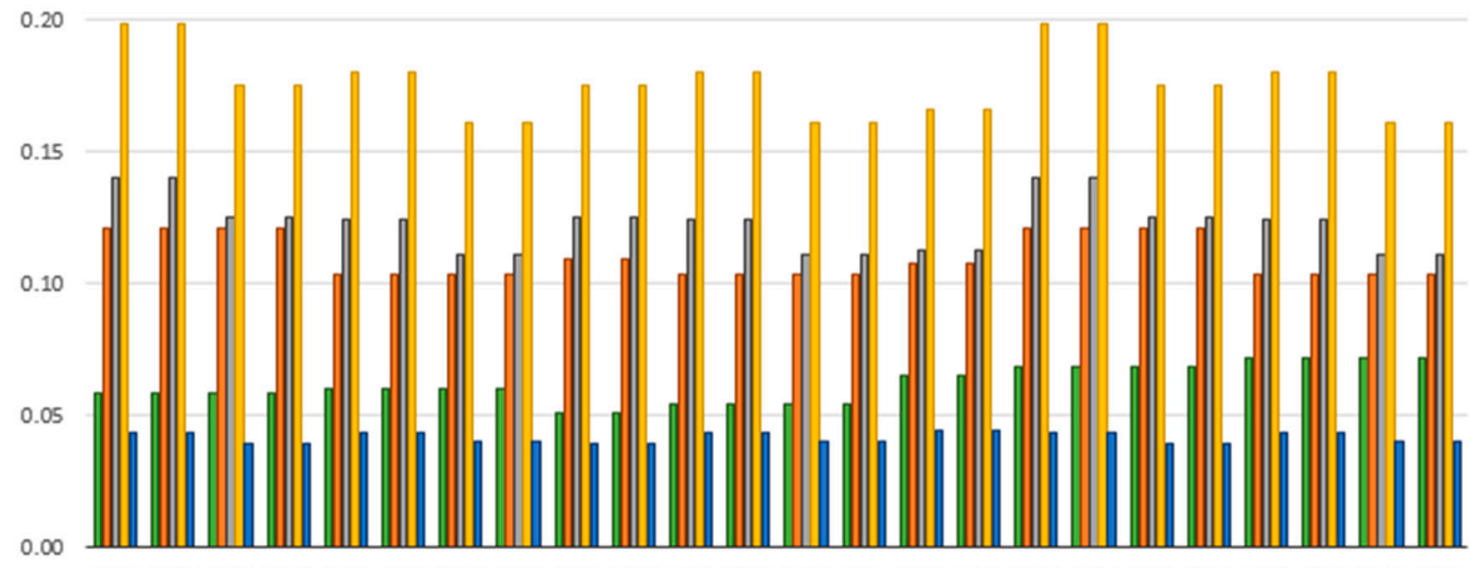

C012 C013 C021 C025 C043 C051 C040 C048 C106 C110 C090 C098 C094 C102 C147 C148 C062 C054 C066 C059 C083 C082 c081 C080

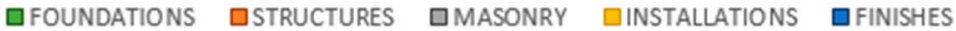

Figure 9. CF per area $\left(\mathrm{tCO}_{2} / \mathrm{m}^{2}\right)$ according to chapter of project (Spain).

A sensitivity analysis of the CF produced by each of the different phases of the projects in each country is carried out, according to the percentage they represent of the total project, which is essential 
for decision-making at the design level in order to focus on the chapters with the greatest impact and to be able to reduce project emissions using more sustainable materials, based on the obtained results of the analysis.

Thanks to the data obtained from the OERCO2 tool, this analysis can be carried out, and it is presented in Tables 9 and 10, depending on whether they are from Spain or Romania, respectively, and grouped according to similarity in terms of building typology.

Table 9. Analysis of CF percentage by project chapters in Spain.

\begin{tabular}{|c|c|c|c|c|c|c|c|c|}
\hline \multicolumn{9}{|c|}{ Project of Spain } \\
\hline & FOUNDATION & \multicolumn{2}{|c|}{ ISOLATED FOOTINGS } & \multicolumn{3}{|c|}{ REINFORCED SLAB } & \multicolumn{2}{|c|}{ PILES } \\
\hline \multicolumn{2}{|c|}{ UGF: Under Ground Floor } & W/O UGF & One UGF & W/O UGF & One UGF & Two UGF & W/O UGF & One UGF \\
\hline \multirow{2}{*}{\multicolumn{2}{|c|}{ CODE }} & $\mathrm{C} 012 / \mathrm{C} 013 /$ & $\mathrm{C} 040 / \mathrm{C} 043 /$ & C106/ & C090/C094/ & C147/ & $\mathrm{C} 054 / \mathrm{C} 059 /$ & C080/C081/ \\
\hline & & $\mathrm{C} 021 / \mathrm{C} 025$ & $\mathrm{C} 048 / \mathrm{C} 051$ & C110 & C098/C102 & C148 & $\mathrm{C} 062 / \mathrm{C} 066$ & $\mathrm{C} 082 / \mathrm{C} 083$ \\
\hline \multirow{6}{*}{ 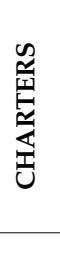 } & FOUNDATION & $9.79 \%$ & $10.89 \%$ & $9.16 \%$ & $9.98 \%$ & $11.47 \%$ & $11.23 \%$ & $12.73 \%$ \\
\hline & STRUCTURES & $20.29 \%$ & $18.67 \%$ & $19.61 \%$ & $18.80 \%$ & $19.05 \%$ & $19.79 \%$ & $18.28 \%$ \\
\hline & MASONRY & $21.81 \%$ & $21.22 \%$ & $22.36 \%$ & $21.37 \%$ & $19.93 \%$ & $21.69 \%$ & $20.78 \%$ \\
\hline & INSTALLATIONS & $30.63 \%$ & $30.81 \%$ & $31.28 \%$ & $31.02 \%$ & $29.29 \%$ & $30.52 \%$ & $30.17 \%$ \\
\hline & FINISHES & $6.79 \%$ & $7.56 \%$ & $6.99 \%$ & $7.61 \%$ & $7.87 \%$ & $6.73 \%$ & $7,40 \%$ \\
\hline & $\%$ CF TOTAL & $89.31 \%$ & $89.15 \%$ & $89.41 \%$ & $88.78 \%$ & $87.61 \%$ & $89.97 \%$ & $89.36 \%$ \\
\hline
\end{tabular}

Table 10. Analysis of CF percentage by project chapters in Romania.

\begin{tabular}{|c|c|c|c|c|c|c|c|c|}
\hline \multicolumn{9}{|c|}{ CF (\%) of Romania Project Chapters } \\
\hline & FOUNDATION & \multicolumn{2}{|c|}{ ISOLATED FOOTINGS } & \multicolumn{3}{|c|}{ REINFORCED SLAB } & \multicolumn{2}{|c|}{ PILES } \\
\hline \multicolumn{2}{|c|}{ UGF: Under Ground Floor } & W/O UGF & One UGF & W/O UGF & One UGF & Two UGF & W/O UGF & One UGF \\
\hline \multirow{2}{*}{\multicolumn{2}{|c|}{ CODE }} & M012/M013 & M040/M043 & M106/ & M090/M094 & M147/ & M054/M059/ & M080/M081/ \\
\hline & & M021/M025 & M048/M051 & M110 & M098/M102 & M148 & M062/M066 & M082/M083 \\
\hline \multirow{6}{*}{ 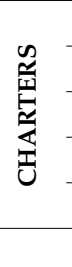 } & FOUNDATION & $7.50 \%$ & $8.56 \%$ & $7.10 \%$ & $7.77 \%$ & $9.39 \%$ & $8.74 \%$ & $9.96 \%$ \\
\hline & STRUCTURES & $34.53 \%$ & $34.12 \%$ & $34.09 \%$ & $33.90 \%$ & $31.81 \%$ & $34.18 \%$ & $33.25 \%$ \\
\hline & MASONRY & $21.57 \%$ & $20.88 \%$ & $22.16 \%$ & $20.82 \%$ & $20.02 \%$ & $21.34 \%$ & $20.35 \%$ \\
\hline & INSTALLATIONS & $22.08 \%$ & $22.10 \%$ & $22.15 \%$ & $22.04 \%$ & $21.82 \%$ & $21.84 \%$ & $21.54 \%$ \\
\hline & FINISHES & $5.30 \%$ & $5.95 \%$ & $5.42 \%$ & $5.93 \%$ & $6.44 \%$ & $5.24 \%$ & $5.79 \%$ \\
\hline & $\%$ CF TOTAL & $90.97 \%$ & $91.61 \%$ & $90.92 \%$ & $90.46 \%$ & $89.48 \%$ & $91.33 \%$ & $90.89 \%$ \\
\hline
\end{tabular}

Thus, in the case of projects in Spain with a concrete structure (Table 9), it can be seen that the foundation for piles is the one with the highest $\mathrm{CF}$, with values between $11.23 \%$ and $12.73 \%$ of the total project impact. The reinforced slab has the lowest CF, 3.57\% less than piles.

In the chapter of structures, it is observed that buildings without underground floors have a higher CF than the rest, and in particular those with foundations with isolated footings, with a $2.01 \%$ difference from those with a lower $\mathrm{CF}$, which are the buildings founded on piles and with a basement.

In the masonry and installation phases, it can be seen that the buildings that have commercial premises on the ground floor produce higher $\mathrm{CFs}$, the difference being $2.43 \%$ for masonry and $1.99 \%$ for installations, between the highest and lowest CF projects.

Regarding cladding, the highest CF corresponds to buildings with the highest number of basement floors and without premises on the ground floor, with a difference of $1.08 \%$ between those with the highest and lowest value.

In the case of the projects in Romania with a metallic structure (Table 10), the projects with foundations of piles are those with the highest CF, with a difference of $2.86 \%$ with respect to the lowest $\mathrm{CF}$, which are those with reinforced slab and without a basement. With respect to Spanish projects, they represent a lower percentage of the total, with an average difference of $2.50 \%$.

The (metallic) structure in the Romanian buildings is the phase with the greatest impact on the project, and it is the foundation with footings that produce the highest $\mathrm{CF}, 2.72 \%$ higher with respect to 
the reinforced slab and two basement floors. With respect to Spanish concrete structures, they have a much higher CF in all cases, the average difference being $14.48 \%$.

In masonry and installations, the situation is similar to Spanish buildings, those with premises on the ground floor and no basement have a higher CF than those without premises and consist of one or two basement floors, with a difference of $2.14 \%$ for masonry and $0.61 \%$ for installations between the highest and lowest with respect to the total CF of the project. The masonry values are very similar to those of the buildings in Spain, however, in the installations, by including the solar panels in Spain, the $\mathrm{CF}$ is higher by an average value of $8.59 \%$.

Cladding has a similar impact in both countries, buildings without premises and with more basement floors produce a higher CF than those with premises on the ground floor and without a basement, with a difference of $1.20 \%$ between those of greater and lesser value. With respect to Spain, Romania has a lower CF of $1.56 \%$.

Finally, an economic and environmental comparison is carried out (Table 11). The economic analysis highlights that MS buildings are more expensive per $\mathrm{m}^{2}$ than CS buildings, and in both cases a pile foundation is the one with the greatest economic impact, followed by isolated footings and reinforced concrete slab. The OERCO2 costs are based on Spanish data.

Table 11. Economic and environmental comparison of MS and CS, according to type of foundation.

\begin{tabular}{ccccccc}
\hline \multirow{3}{*}{ Foundation } & \multicolumn{3}{c}{ Concrete Structure (CS) } & \multicolumn{3}{c}{ Metallic Structure (MS) } \\
\cline { 2 - 7 } & \multicolumn{3}{c}{ Cost } & \multicolumn{3}{c}{ Cost } \\
\cline { 2 - 7 } & \multicolumn{2}{c}{ Economic } & Environmental & Economic & Environmental \\
\cline { 2 - 7 } & ACCD (Spain) & European & $\mathbf{C F}$ & ACCD (Spain) & European & $\mathbf{C F}$ \\
\hline Isolated footings & 647.64 & 861.22 & 0.571 & 777.11 & 1033.39 & 0.740 \\
\hline Reinforced slab & 639.05 & 849.80 & 0.556 & 754.80 & 1003.72 & 0.720 \\
\hline Piles & 697.42 & 927.42 & 0.588 & 821.44 & 1092.34 & 0.753 \\
\hline
\end{tabular}

The Romanian construction cost can be translated into Spanish cost by normalization tools such as European Construction Cost data [73,74], the coefficient for Spanish costs is 0.7052 and for Romanian costs, it is 0.464 . In the present work the Spanish costs are used for both countries in order to facilitate the results comparison (Table 11).

Regarding the CF, MS buildings produce the highest emissions and pile foundations produce the greatest impact in both types of buildings, followed by isolated footings and, lastly, reinforced slab. These results are similar to others [68]. Materials (including their transport) are responsible for $95-97 \%$ of project emissions. The remaining percentage corresponds to machinery.

Muñoz et al. (2012) [75] carried out a study of the CF of social housing built in Chile, focusing on the LCA of construction materials, which included its implementation. The results showed that the energy of commissioning is negligible, while $35 \%$ corresponds to the extraction and manufacture of materials, and $65 \%$ to the use and maintenance. In addition, there are bibliographic reviews related to the use of the CF indicator in construction [28], however, the results are not always comparable due to the absence of a methodology that follows international standards [29]. For this reason, studies have also been carried out in recent years to establish scales that allow for defining reasonable ranges of $\mathrm{CO}_{2}$ emissions in construction processes [30].

\section{Conclusions}

The OERCO2 tool is valid to compare constructive solutions between different project partner countries (in this case, Romania and Spain), because the tool includes the representative characteristics of the buildings in the partner countries. The tool allows for analyzing different constructive systems, in this case, the different types of foundations, structures, masonry, or installations that have been 
proposed. Therefore, it is possible to determine which constructive solution has the least impact from an economic and environmental point of view. According to the analyzed cases, the most efficient typologies are reinforced concrete buildings, with a significant difference with respect to metallic structures, both economically and environmentally.

For the 48 analyzed typologies, the families of materials that produce the most emissions are: metals/alloys, concretes/cements, and ceramics/bricks and, to a lesser extent, plastics. The structures, installations, foundations, and finishes produce the greatest impacts.

The OERCO2 tool evaluates a project's CF and economic impact simultaneously at the design stage and in detail, according to the project phases, such as earthwork, foundation, structure, etc. Decisions can be made regarding the construction systems and materials used in order to reduce emissions and economic impact, thus helping to understand and improve the eco-efficiency of projects. Therefore, OERCO2 can be a useful educational tool for architecture and engineering college students.

Of the types of foundation assessed both economically and environmentally, piles produce the highest emissions and cost, and the best option is reinforced slabs followed by insulated footings. The building ground floor use, as a dwelling or premises, also influences cost and emissions, especially in phases such as masonry, installations, or finishes.

All these analyses are important to decide how to design in the most environmentally friendly and economical way. The tool facilitates the decision-making of promoters and technicians, without needing prior knowledge about environmental indicators.

Supplementary Materials: The following are available online at http://www.mdpi.com/2071-1050/12/17/6745/s1, Table S1: Unit quantities (Qi) according to OERCO2 coding in Romanian projects based on building typology and construction characteristics, Table S2: Unit quantities (Qi) according to OERCO2 coding in Spanish Projects based on building typology and construction characteristics.

Author Contributions: All the authors have equally contributed to the final version of this paper. All authors have read and agreed to the published version of the manuscript.

Funding: This work has received funding from the University of Seville and the Junta de Andalucía for the consolidation of the research groups. Reference: TEP-172. 1821012924 (2020/595) and the VI Own Research and Transfer Plan of the University of Seville (VI PPIT-US). This research is also funded by the project: Andalusian Ecological Certificate for Building Construction According to Environmental Indicators Carbon, Ecological and Water Footprint (CEACE). Reference AT17_5913_USE. Financed within the PAIDI 2020 call: Knowledge Transfer Activities by the Ministry of Economy and Knowledge of the Andalusian Government (Spain).

Acknowledgments: This research has been carried out thanks to the OERCO2 project (code 2016-1-ES01KA203-025422), an ERASMUS + project co-financed by the European Union and within the framework of an initiative in 2016 (KA2, strategic alliances in the field of education superior), with the support of the Spanish Service for the Internationalization of Education (SEPIE, Spain).

Conflicts of Interest: The authors declare no conflict of interest.

\section{References}

1. European Parliament-Council of the European Union DIRECTIVE (EU) 2018/844 of the European Parliament and of the Council of 30 May 2018 amending Directive 2010/31/EU on the Energy Performance of Buildings and Directive 2012/27/EU on Energy efficiency (Text with EEA Relevance). Available online: http://data. europa.eu/eli/dir/2018/844/oj (accessed on 1 August 2020).

2. UNE, Normalización Española. UNE-EN ISO 14020 Environmental Labels and Declarations_General Principles; UNE: Madrid, Spain, 2002.

3. UNE, Normalización Española. UNE-EN ISO 14025 Environmental Labels and Declarations-Type III Environmental Declarations_Principles and Procedures; UNE: Madrid, Spain, 2006.

4. UNE, Normalización Española. UNE-EN 15804 Sustainability of Construction Works-Environmental Product Declarations -Core Rules for the Product Category of Construction Products; UNE: Madrid, Spain, 2012.

5. UNE, Normalización Española. UNE-EN ISO 14021 Environmental Labels and Declarations-Self-Declared Environmental Claims (Type II Environmental Labelling); UNE: Madrid, Spain, 2017.

6. UNE, Normalización Española. UNE-EN ISO 14040 Environmental Management_Life Cycle Assessment_Principles and Framework; UNE: Madrid, Spain, 2006. 
7. UNE, Normalización Española. UNE-EN ISO 14044 Environmental Management_Life Cycle AssessmentRequirements and Guidelines; UNE: Madrid, Spain, 2006.

8. UNE, Normalización Española. UNE-EN 15978 Sustainability of Construction Works. Assessment of Environmental Performance of Buildings. Calculation Methods; UNE: Madrid, Spain, 2012.

9. UNE, Normalización Española. UNE-EN ISO 14001 Environmental Management Systems_Requirements with Guidance for Use; UNE: Madrid, Spain, 2015.

10. International Organization for Standardization (ISO). ISO 15686-5 Buildings and Constructed Assets-Service Life Planning-Part 5: Life-Cycle Costing; ISO: Geneva, Switzerland, 2017.

11. Giesekam, J.; Barrett, J.R.; Taylor, P. Construction sector views on low carbon building materials. Build. Res. Inf. 2016, 44, 423-444. [CrossRef]

12. Giesekam, J.; Barrett, J.; Taylor, P.; Owen, A. The greenhouse gas emissions and mitigation options for materials used in UK construction. Energy Build. 2014, 78, 202-214. [CrossRef]

13. Asif, M.; Muneer, T.; Kelley, R. Life cycle assessment: A case study of a dwelling home in Scotland. Build. Environ. 2007, 42, 1391-1394. [CrossRef]

14. Dimoudi, A.; Tompa, C. Energy and environmental indicators related to construction of office buildings. Resour. Conserv. Recycl. 2008, 53, 86-95. [CrossRef]

15. Radhi, H.; Sharples, S. Global warming implications of facade parameters: A life cycle assessment of residential buildings in Bahrain. Environ. Impact Assess. Rev. 2013, 38, 99-108. [CrossRef]

16. You, F.; Hu, D.; Zhang, H.; Guo, Z.; Zhao, Y.; Wang, B.; Yuan, Y. Carbon emissions in the life cycle of urban building system in China-A case study of residential buildings. Ecol. Complex. 2011, 8, 201-212. [CrossRef]

17. Cellura, M.; Guarino, F.; Longo, S.; Mistretta, M. Energy life-cycle approach in Net zero energy buildings balance: Operation and embodied energy of an Italian case study. Energy Build. 2014, 72, 371-381. [CrossRef]

18. Scheuer, C.; Keoleian, G.A.; Reppe, P. Life cycle energy and environmental performance of a new university building: Modeling challenges and design implications. Energy Build. 2003, 35, 1049-1064. [CrossRef]

19. Buyle, M.; Braet, J.; Audenaert, A. Life cycle assessment in the construction sector: A review. Renew. Sustain. Energy Rev. 2013, 26, 379-388. [CrossRef]

20. Ramesh, T.; Prakash, R.; Shukla, K.K. Life cycle energy analysis of buildings: An overview. Energy Build. 2010, 42, 1592-1600. [CrossRef]

21. Schwartz, Y.; Raslan, R.; Mumovic, D. The life cycle carbon footprint of refurbished and new buildings-A systematic review of case studies. Renew. Sustain. Energy Rev. 2018, 81, 231-241. [CrossRef]

22. Cabeza, L.F.; Rincón, L.; Vilariño, V.; Pérez, G.; Castell, A. Life cycle assessment (LCA) and life cycle energy analysis (LCEA) of buildings and the building sector: A review. Renew. Sustain. Energy Rev. 2014, 29, 394-416. [CrossRef]

23. Chau, C.K.; Leung, T.M.; Ng, W.Y. A review on life cycle assessment, life cycle energy assessment and life cycle carbon emissions assessment on buildings. Appl. Energy 2015, 143, 395-413. [CrossRef]

24. Marrero, M.; Wojtasiewicz, M.; Martínez-Rocamora, A.; Solís-Guzmán, J.; Alba-Rodríguez, M.D. BIM-LCA Integration for the Environmental Impact Assessment of the Urbanization Process. Sustainability 2020, 12, 4196. [CrossRef]

25. Weidema, B.P.; Thrane, M.; Christensen, P.; Schmidt, J.; Løkke, S. Carbon Footprint. A Catalyst for Life Cycle Assessment? J. Ind. Ecol. 2008, 12, 3-6. [CrossRef]

26. Cagiao, J.; Gómez, B.; Doménech, J.L.; Gutiérrez Mainar, S.; Gutiérrez Lanza, H. Calculation of the corporate carbon footprint of the cement industry by the application of MC3 methodology. Ecol. Indic. 2011, 11, 1526-1540. [CrossRef]

27. Bare, J.C.; Hofstetter, P.; Pennington, D.W.; Haes, H.A.U. Midpoints versus endpoints: The sacrifices and benefits. Int. J. Life Cycle Assess. 2000, 5, 319-326. [CrossRef]

28. Geng, S.; Wang, Y.; Zuo, J.; Zhou, Z.; Du, H.; Mao, G. Building life cycle assessment research: A review by bibliometric analysis. Renew. Sustain. Energy Rev. 2017, 76, 176-184. [CrossRef]

29. Dossche, C.; Boel, V.; De Corte, W. Use of Life Cycle Assessments in the Construction Sector: Critical Review. Procedia Eng. 2017, 171, 302-311. [CrossRef]

30. Chastas, P.; Theodosiou, T.; Kontoleon, K.J.; Bikas, D. Normalising and assessing carbon emissions in the building sector: A review on the embodied CO2 emissions of residential buildings. Build. Environ. 2018, 130, 212-226. [CrossRef] 
31. Oregi Isasi, X.; Tenorio, J.A.; Gazulla, C.; Zabalza, I.; Cambra, D.; Leao, S.O.; Mabe, L.; Otero, S.; Raigosa, J. SOFIAS-Software for life-cycle assessment and environmental rating of buildings. Inf. De La Constr. 2016, 68. [CrossRef]

32. SpainGBC VERDE Tool Website. Available online: http://www.gbce.es/es/pagina/herramientas-deevaluacion-de-edificios (accessed on 22 November 2019).

33. BREEAM.ES Website. Available online: http://www.breeam.es/ (accessed on 9 November 2019).

34. Asociación Ecómetro Ecometro LCA Tool Website. Available online: http://acv.ecometro.org/ (accessed on 9 November 2019).

35. SOFIAS Project SOFIAS Project Website. Available online: http://www.sofiasproject.org/ (accessed on 9 November 2019).

36. e2CO2cero Tool Website. Available online: http://tienda.e2co2cero.com/ (accessed on 9 November 2019).

37. Ecoinvent Centre Ecoinvent Database. Available online: http://www.ecoinvent.org/database/ (accessed on 15 November 2019).

38. Martínez-Rocamora, A.; Solís-Guzmán, J.; Marrero, M. LCA databases focused on construction materials: A review. Renew. Sustain. Energy Rev. 2016, 58, 565-573. [CrossRef]

39. PRé Sustainability SimaPro 8. Available online: https://simapro.com/ (accessed on 9 November 2019).

40. Council, G.S.B. DGNB. German Sustainable Building Council. Available online: https://www.dgnb.de/en/ index.php (accessed on 7 June 2020).

41. Romania Green Building Council GREEN HOMES Certification System. Available online: www.rogbc.org (accessed on 7 June 2020).

42. Integrated Environmental Solutions Limited Intelligent Communities Lifecycle. Available online: https: //www.iesve.com/ (accessed on 26 November 2019).

43. Popiț, G.-E.; Baciu, C.; Rédey, A.; Frunzeti, N.; Ionescu, A.; Yuzhakova, T.; Popovici, A. Life cycle assessment (LCA) of municipal solid waste management systems in Cluj County, Romania. Environ. Eng. Manag. J. 2017, 16, 47-57.

44. 360 Optimi. Available online: https://www.360optimi.com/app/sec/main/list (accessed on 5 July 2020).

45. Colliers International Romania. Available online: https://www.oneclicklca.com/case-study-warehouseromania-leed/ (accessed on 4 July 2020).

46. Living Building Challenge Standard 3.0. Available online: https://living-future.org/ (accessed on 5 July 2020).

47. University of Seville and Partners OERCO2. Available online: http://oerco2.eu/es/ (accessed on 21 June 2020).

48. Solís-Guzmán, J.; Rivero-Camacho, C.; Alba-Rodríguez, D.; Martínez-Rocamora, A. Carbon footprint estimation tool for residential buildings for non-specialized users: OERCO2 project. Sustainability 2018, 10, 1359. [CrossRef]

49. Proiectare, P.D.E. COD DE PROIECTARE SEISMIC $\breve{-P A R T E A ~ I — P E N T R U ~ C L A ̆ D I R I ; ~ M i n i s t e r u l ~ L u c r a ̆ r i l o r ~}$ Publice, Dezvoltării și Administrației: Bucharest, Romania, 2013.

50. González-Vallejo, P.; Marrero, M.; Solís-Guzmán, J. The ecological footprint of dwelling construction in Spain. Ecol. Indic. 2015, 52, 75-84. [CrossRef]

51. Solís-Guzmán, J.; González-Vallejo, P.; Martínez-Rocamora, A.; Marrero, M. The Carbon Footprint of Dwelling Construction in Spain. In The Carbon Footprint Handbook; Taylor and Francis Group: Abingdon, UK, 2015; Volume 1, pp. 261-263. ISBN 978-1-4822-6222-3.

52. Solís-Guzmán, J.; Marrero, M.; Ramírez-de-Arellano, A. Methodology for determining the ecological footprint of the construction of residential buildings in Andalusia (Spain). Ecol. Indic. 2013, 25, 239-249. [CrossRef]

53. Solís-Guzmán, J.; Marrero, M.; Montes-Delgado, M.V.; Ramírez-de-Arellano, A. A Spanish model for quantification and management of construction waste. Waste Manag. 2009, 29, 2542-2548. [CrossRef]

54. Martínez-Rocamora, A.; Solís-Guzmán, J.; Marrero, M. Ecological footprint of the use and maintenance phase of buildings: Maintenance tasks and final results. Energy Build. 2017, 155, 339-351. [CrossRef]

55. Marrero, M.; Puerto, M.; Rivero Camacho, C.; Freire Guerrero, A.; Solís-Guzmán, J. “Assessing the economic impact and ecological footprint of construction and demolition waste during the urbanization of rural land". Resour. Conserv. Recycling. Resour. Conserv. Recycl. 2017, 117, 160-174. [CrossRef]

56. González-Vallejo, P.; Muñoz-Sanguinetti, C.; Marrero, M. Environmental and economic assessment of dwelling construction in Spain and Chile. A comparative analysis of two representative case studies. J. Clean. Prod. 2019, 208, 621-635. [CrossRef] 
57. Marrero, M.; Ramírez de Arellano Agudo, A. The building cost system in Andalusia: Application to construction and demolition waste management. Constr. Manag. Econ. 2010, 28, 495-507. [CrossRef]

58. Consejería de Fomento y Vivienda Junta de Andalucía. Consejería de Fomento y Vivienda. Available online: https:/www.juntadeandalucia.es/organismos/fomentoinfraestructurasyordenaciondelterritorio/ areas/vivienda-rehabilitacion/planes-instrumentos/paginas/bcca-sept-2017.html (accessed on 3 July 2020).

59. Marrero, M.; Rivero-camacho, C.; Alba-rodríguez, M.D. What are we discarding during the life cycle of a building? Case studies of social housing in Andalusia, Spain. Waste Manag. 2020, 102, 391-403. [CrossRef] [PubMed]

60. González-Vallejo, P. Herramienta para la estimación de costes económicos y ambientales en el ciclo de vida de edificios residenciales. Fase de construcción. Hábitat SustenTable 2018, 8, 32-51. [CrossRef]

61. Alba Rodríguez, D.; Ferreira Sánchez, A.; Marrero, M.; Ramirez de Arellano Agudo, A. Ecological Footprint of Building Recovery: Foundation Pinning Under Emergency Conditions. In Proceedings of the II International Congress on Sustainable Construction and Eco-Efficient Solutions, Seville, Spain, 25-27 May 2015; pp. $35-45$.

62. González-Vallejo, P.; Solís-Guzmán, J.; Llácer, R.; Marrero, M. La construcción de edificios residenciales en España en el período 2007-2010 y su impacto según el indicador Huella Ecológica. Inf. De La Construcción 2015, 67, e111. [CrossRef]

63. Instituto para la Diversificación y Ahorro de la Energía (IDAE) Conducción Eficiente de Vehículos Industriales. Informe del Instituto para la Diversificación y Ahorro de la Energía; IDAE: Madrid, Spain, 2012.

64. REE. Red Eléctrica Española Avance; Red Eléctrica de España: Madrid, Spain, 2015.

65. Autoritatea Nationala de Reglementare in Domeniul Energiei. Available online: https://www.anre.ro/en/ about-anre/annual-reports-archive (accessed on 21 June 2020).

66. Freire-Guerrero, A.; Alba-Rodríguez, M.D.; Marrero, M. A budget for the ecological footprint of buildings is possible: A case study using the dwelling construction cost database of Andalusia. Sustain. Cities Soc. 2019, 51, 101737. [CrossRef]

67. Spain Government. Instrucción de Hormigón Estructural. Structural Concrete Instruction, Normative Series 2011; Spain Government: Madrid, Spain, 2008.

68. Solís-Guzmán, J.; Rivero-Camacho, C.; Tristancho, M.; Martínez-Rocamora, A.; Marrero, M. Software for Calculation of Carbon Footprint for Residential Buildings. In Environmental Footprints and Eco-Design of Products and Processes; Springer: Berlin, Germany, 2020; pp. 55-79.

69. National Institute of Statistics of Romania. Organization and Functioning of Official Statistics in Romania. Available online: http://www.insse.ro/cms/en/content/official-statistics-romania (accessed on 5 February 2019).

70. Romanian Government. Strategia Natională a Locuirii 2017-2030; Romanian Government: Bucharest, Romania, 2017.

71. Bruno, M.; Pleskovic, B. Proceedings of the World Bank Annual Conference on Development Economics, 1994; World Bank Group: Washington, DC, USA, 1995; ISBN 0821329081.

72. Instituto Nacional de Estadísticas (INE) de España. Censo de Población y Viviendas; INE: Madrid, Spain, 2001.

73. De Groot, I.B.; Bucknal, R.L. European Construction Costs. Available online: http://constructioncosts.eu/ (accessed on 3 August 2020).

74. Vázquez-López, E.; Garzia, F.; Pernetti, R.; Solís-Guzmán, J.; Marrero, M. Assessment model of end-of-life costs and waste quantification in selective demolitions: Case studies of nearly zero-energy buildings. Sustainability 2020, 12, 6255. [CrossRef]

75. Muñoz, C.; Zaror, C.; Saelzer, G.; Cuchí, A. Estudio del flujo energético en el ciclo de vida de una vivienda y su implicancia en las emisiones de gases de efecto invernadero, durante la fase de construcción Caso Estudio: Vivienda Tipología Social. Región del Biobío, Chile. Rev. De La Construcción 2012, 11, 125-145. [CrossRef]

(C) 2020 by the authors. Licensee MDPI, Basel, Switzerland. This article is an open access article distributed under the terms and conditions of the Creative Commons Attribution (CC BY) license (http://creativecommons.org/licenses/by/4.0/). 